\title{
36. AUTHIGENIC AND DETRITAL “GLAUCONIE” ENCOUNTERED IN LEG 29 SEDIMENTS
}

Walter C. Dudley and Stanley V. Margolis, Department of Oceanography,

Hawaii Institute of Geophysics, University of Hawaii, Honolulu, Hawaii

\section{INTRODUCTION}

The term "glauconie" (Millot, 1970) refers to any of a number of green clay minerals ranging from the mineral glauconite with an ordered or disordered dioctahedral micaceous lattice to a variable mixture of illite, montmorillonite, or chlorite. In the literature the depths of glauconie occurrence have been described as being restricted to between 30 and 2000 meters (Porrenge, 1966). Various modes of formation of glauconie have been outlined including neoformation inside foraminifera shells (Ehlman et al., 1963) and transformation of biotite (Galliher, 1935).

The study of sediments from DSDP Leg 29 revealed the occurrence of glauconie in significant amounts at Sites 275, 277, 280, 280 (Hole 280A), and 281, showing a depth range from 1200 to 4200 meters. At these sites the occurrence of glauconie includes detrital grains, internal molds and fillings in foraminifera, and transformed biotite.

\section{Techniques}

Sediment samples were washed and wet sieved. The greater than $44 \mu$ fraction was examined for the occurrence of glauconie under a $20 \times$ to $100 \times$ reflected light microscope. Representative grains of glauconie were picked, mounted, and carbon coated for examination with a Cambridge S4 scanning electron microscope (SEM), and for energy dispersive analysis of X-rays (EDAX).

\section{RESULTS}

\section{Site 275 (depth $2840 \mathrm{~m}$ )}

Glauconie is a significant sediment component in Cores 1 and 2. A complete sequence of transformation from biotite to glauconie was found in every sample. Unaltered and slightly altered biotite was present, in addition to biotite entirely altered to a green color. Grains in the next sequence were swollen, especially along the cleavages (Plate 1; Figure 1), and had taken on an accordion shape (Plate 1; Figure 2). Expansion perpendicular to the original biotite cleavage continued (Plate 1; Figure 3) until grains lost all resemblance to their parent mineral. Galliher (1935) has suggested that grains at this stage, upon passing through the digestive tracts of muddwelling organisms, could be molded into coprolites. Such shapes are common in all the Site 275 samples of glauconie. EDAX revealed a progressive increase in the silica and iron content, and decrease in the aluminum, potassium, and magnesium content, at various stages in the transformation from biotite to glauconie (Table 1).
TABLE 1

Chemical Composition of Glauconite Grains Representative of the Different Morphological Types Found in Leg 29 Sediments, Compared with Igneous Biotite Standard

\begin{tabular}{c|cccr}
\hline & \multicolumn{4}{|c}{ Relative Peak Heights (\%) } \\
\cline { 2 - 5 } Element & $\begin{array}{c}\text { Biotite } \\
\text { Laboratory } \\
\text { Standard }\end{array}$ & $\begin{array}{c}\text { Transformed } \\
\text { Biotite } \\
\text { Glauconie }\end{array}$ & $\begin{array}{c}\text { Infilled } \\
\text { Foram } \\
\text { Glauconie }\end{array}$ & $\begin{array}{c}\text { Detrital } \\
\text { Glauconie }\end{array}$ \\
\hline $\mathrm{Si}$ & 44.9 & 57.2 & 49.1 & 53.1 \\
$\mathrm{AL}$ & 9.6 & 4.4 & 5.6 & 8.4 \\
$\mathrm{Fe}$ & 11.4 & 19.9 & 23.8 & 22.1 \\
$\mathrm{~K}$ & 20.0 & 14.6 & 19.4 & 14.9 \\
$\mathrm{Mg}$ & 13.8 & 3.7 & 2.0 & 1.6 \\
Total & $99.7 \%$ & 99.8 & 99.9 & 100.1 \\
\hline
\end{tabular}

Note: Analysis was performed using an EDAX microanalyzer. Percentages were calculated by counting on each grain under similar excitation conditions and lengths of time, and comparing $\mathrm{K} \alpha$ peak height ratios, after background and atomic number corrections.

\section{Site 277 (depth 1208 m)}

Glauconie was a significant component in Core 2 . Much of this glauconie was light green in color, and either occurred inside the shells of planktonic foraminifera (Plate 1; Figure 5), or was in the shape of the internal molds of foraminifera shells (Plate 1; Figure 6). The foraminifera shells do not appear abraded by reworking or transportation. EDAX revealed that the composition of the darker green glauconie is characteristic of glauconite (Table 1), and that the lighter green and yellow glauconie is deficient in potassium and iron.

\section{Site 280 (depth $\mathbf{4 1 8 5} \mathrm{m}$ )}

Glauconie is a common sediment component in Core 1. The occurrence is very similar to that at Site 275 , showing a progressive transformation of biotite to glauconite.

Glauconie from Hole 280A (Cores 6, 13, 15) gives no suggestion as to mode of formation. Individual grains exhibit broken irregular outlines with fairly smooth surfaces (Plate 1, Figure 4), indicative of detrital origin (Light, 1952). These grains are almost exclusively dark green in color and have a composition characteristic of glauconite (Table 1).

\section{Site 281 (depth $1600 \mathrm{~m}$ )}

The occurrence of glauconie in Core 13 at Site 281 is another example of the transformation of biotite to glauconie. All the various stages are present and exhibit the characteristics described for samples at Sites 275 and 280 . 


\section{DISCUSSION}

\section{Sedimentation Rates}

With the exception of the glauconie at Site 280 (Hole $280 \mathrm{~A}$ ), all occurrences were associated with sedimentation rates between 4 and $10.2 \mathrm{~m} / \mathrm{m} . \mathrm{y} .{ }^{1}$ The transformation of biotite and the neoformation of glauconie apparently require prolonged contact with seawater, an ion source, and therefore are characteristic of slow sedimentation. The sedimentation rate of the glauconie occurrence at Site 280 is $39 \mathrm{~m} / \mathrm{m} . \mathrm{y}$. The associated sediment, and the features of the glauconie, indicate a detrital origin. Whether the detrital glauconie is derived from a terrestrial source, or has merely undergone abrasion due to marine transport and reworking, is not yet known.

\section{Surface Features}

When observed under high magnification with the SEM, the various types of glauconie exhibited distinctive surface features. The detrital grains were quite smooth and showed no indication of structural influence (Plate 2, Figure 1). The transformed biotite, on the other hand, clearly exhibited the preexisting sheet structure of the parent mineral, but with the plates widely spaced due to the considerable expansion (Plate 2, Figure 2). The neoformed glauconie in the foraminifera shells was characterized by a spongy arrangement of thin bladeshaped crystals, in some cases showing definite overall orientations (Plate 2, Figure 3).

\section{Chemical Composition}

Comparison of relative peak heights of EDAX analysis revealed certain definite compositional trends

${ }^{1}$ Sedimentation rate in Cretaceous portion at Site 275 is unknown.
(Table 1). The transformation of biotite results in enrichment in silicon and iron, and an accompanying decrease in aluminum, potassium, and magnesium. These trends agree with those found by Galliher (1935).

The neoformation of glauconie in foraminifera shells showed a progressive increase in potassium and iron, with a change in color of the internal filling from lighter to darker green. The detrital glauconie grains analyzed all occurred within a fairly narrow composition range.

The occurrences of glauconie when compared to the associated sediments, revealed no apparent trends other than foraminifera-rich sediments naturally being associated with glauconie-filled foraminifera. Accompanying sediments ranged from siliceous to nannofossil oozes. In every case other clay minerals were present as possible ion sources. The comparison of glauconie occurrences with depth showed a range from 1200 meters at Site 277 , to 4200 meters at Site 280 . However, glauconie filled foraminifera were abundant only in the relatively shallow water at Site 277 . The glauconie occurrences dated by the associated microfossils show no apparent restrictions as to geologic time. Potassiumargon dating of glauconie samples is discussed by Adams (this volume) and may provide evidence as to the source area of the detrital glauconie.

\section{REFERENCES}

Ehlmann, A. J., Hulings, N. C., and Glover, E. D., 1963. Stages of glauconite formations in modern foraminifera sediments: J. Sediment Petrol., v. 33, p. 87-96.

Galliher, W. E., 1935. Glauconite genesis: Geol. Soc. Am. Bull., v. 46, p. 1351-1366.

Light, M. A., 1952, Evidence of authigenic and detrital glauconite: Science, v. 115(2977), p. 73-75.

Millot, G., 1970. Geology of clays: New York (SpringerVerlag), p. 204-210.

Porrenge, D. H., 1966. Glauconite and chamosite as depth indicators in the marine environment: Marine Geol., v. 5, p. 495-501. 


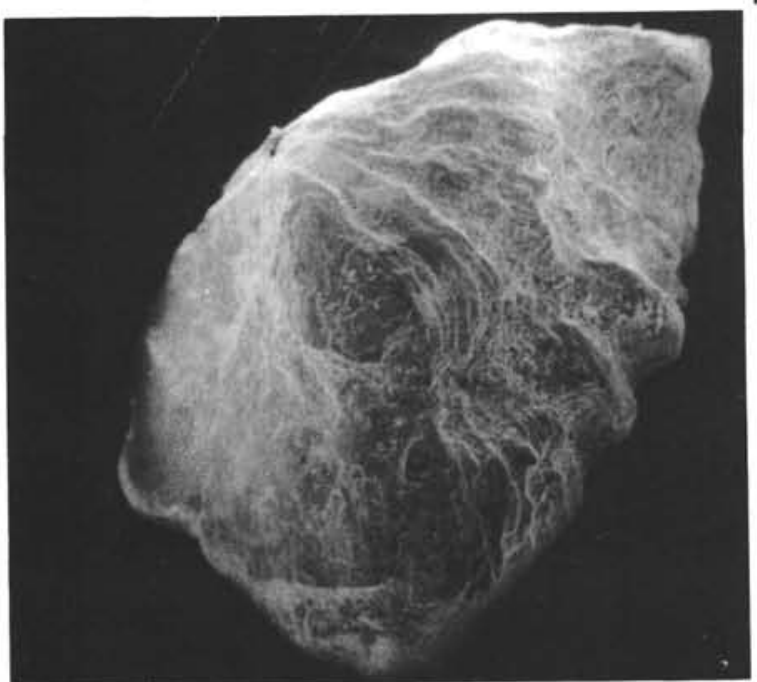

PLATE

1

$100 \mu$
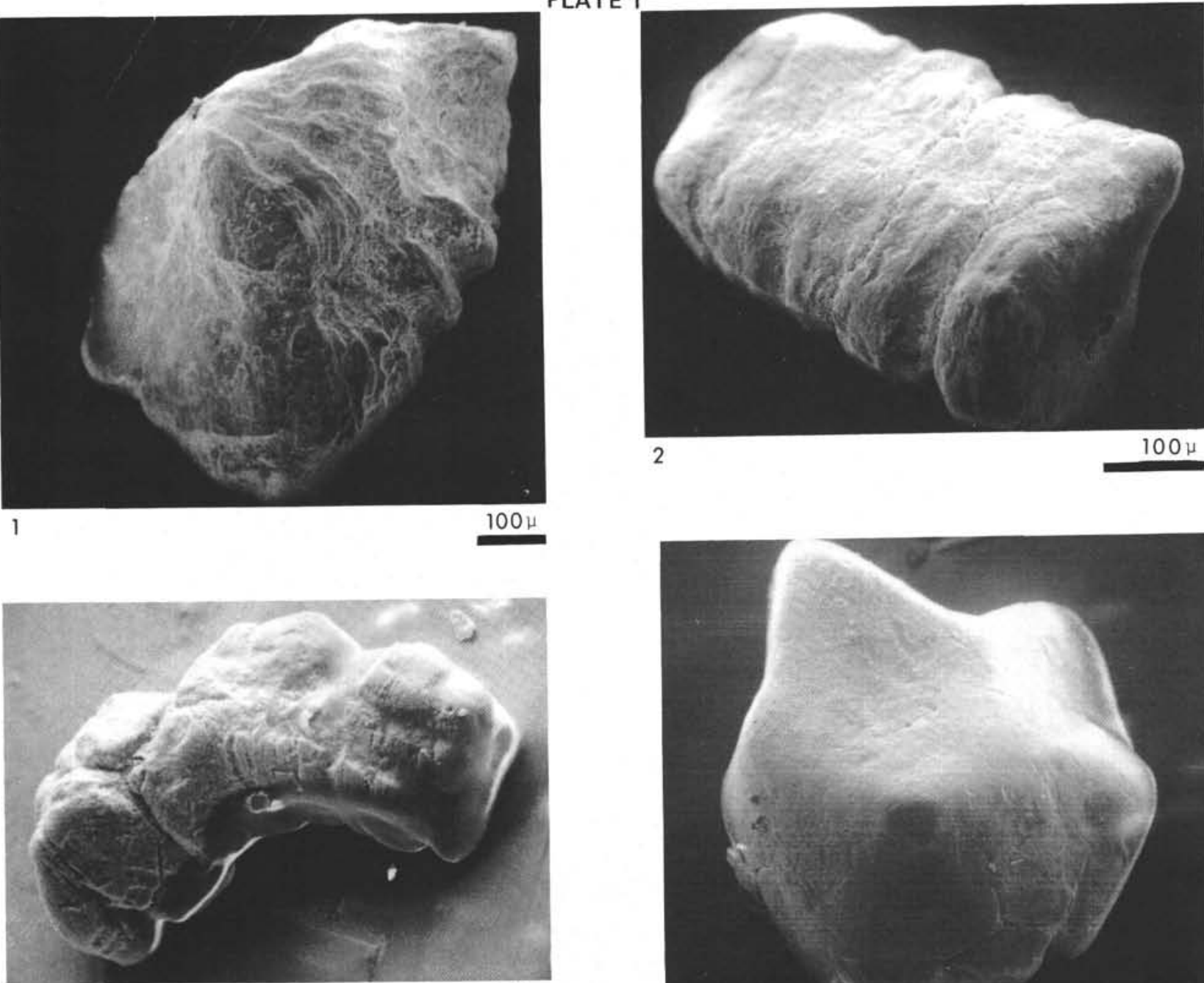

3
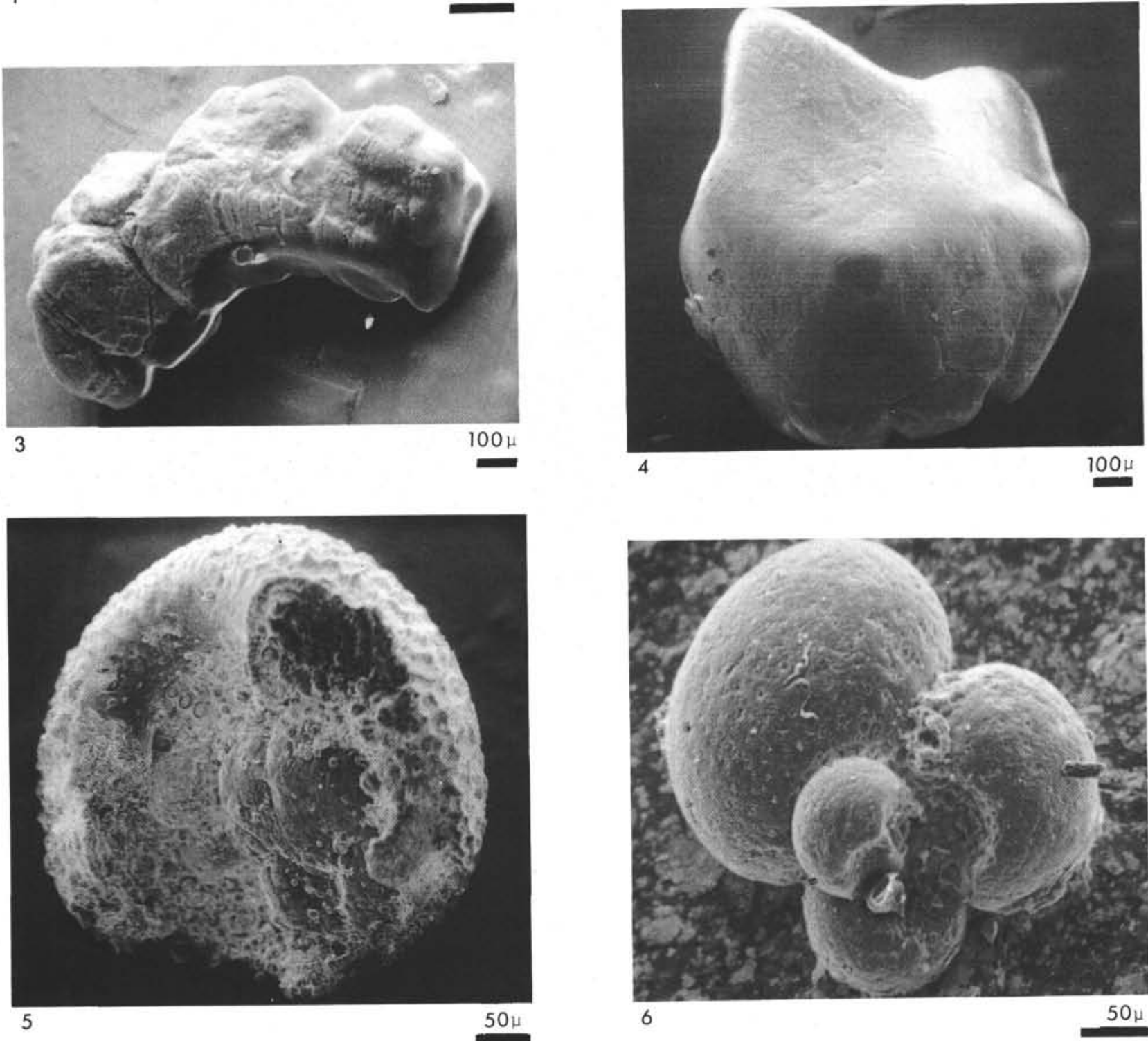

Figures 1, 2, 3 Altered biotite grains in progressive stages of transformation to glauconie.

Figure 4 Detrital glauconie grain.

Figure 5

Glauconie "growing" inside foraminifera shell.

Figure 6 Glauconie mold of a foraminifera. 
PLATE 2
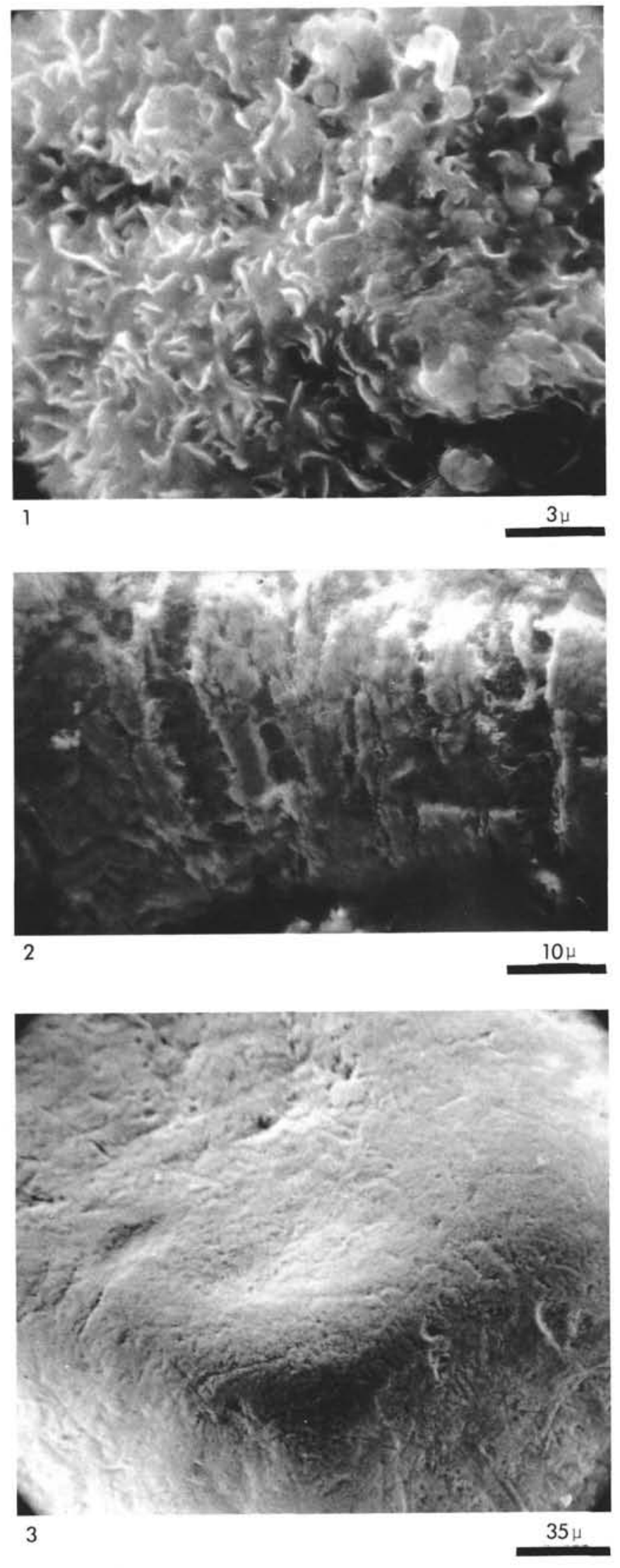

Figure 1

Figure 2

Surface features of neoformed glauconie.

Figure 3 Surface features of transformed biotite. Surface features of detrital glauconie grain. 